\title{
GRAVAÇÃO CLANDESTINA DE CONVERSA
}

\author{
Marco Aurélio Costa Moreira de Oliveira ${ }^{1}$
}

\section{RESUMO}

$\mathrm{O}$ artigo traz reflexões sobre aspectos éticos, sociais e jurídicos de gravações clandestinas de conversas particulares.

Descritores: Gravação clandestina: ética. Prova ilícita. Direito à privacidade. Direito ao sigilo. Informação. Comunicação social.

\section{INTRODUÇÃO}

As gravações de conversas particulares feitas por um dos participantes, sem autorização judicial, demonstram-se manifestamente ilegais. Aliás, nossa orientação jurisprudencial, no- tadamente a do Supremo Tribunal, não deixa dúvidas quanto à ilegitimidade desse procedimento. Ressalvam-se apenas os casos em que se pretenda resguardar direito individual do autor da gravação, pois é lícito que, em favor de suas prerrogativas pessoais, possa obter provas a si favoráveis, até mesmo como uma forma de legítima defesa, quando houver necessidade de preservar direitos ameaçados.

\section{ASPECTOS ÉTICOS, SOCIAIS E JURÍDICOS}

Mas não precisamos nos socorrer de soluções jurídicas para bem formar um juízo ético sobre tais espécies de gravações clandestinas.

1 Professor Adjunto de Ciências Penais da Faculdade de Direito da Universidade Federal do Rio Grande do Sul (UFRGS). Currículo: http://buscatextual.cnpq.br/buscatextual/visualizacv.jsp?id=K4217676P6. Endereço profissional: Av. João Pessoa, 80, térreo, Centro, Porto Alegre, Rio Grande do Sul, Brasil, CEP 90.040-000. Endereço eletrônico: marcoaurelio@moreiradeoliveira.com.br. 
Se fosse eticamente sustentável realizar uma gravação sobre conversas particulares, sem conhecimento do interlocutor, ingressaríamos em uma fase social de profundo desconforto, de incertezas sobre o limite do relacionamento humano, de intranquilidade e, certamente, partiríamos para um isolamento capaz de mumificar a sensibilidade dos homens.

A gravação clandestina, se fosse eticamente saudável, reviveria o velho discurso que defende serem os meios justificados pelos fins.

Ora, os seres humanos necessitam confiar uns nos outros; e se alguém procura outrem para trocar ideias deve ter a certeza de estar estabelecendo uma confiança recíproca. A desconfiança nos seres humanos, gerada pela permissibilidade de fraudar o sigilo de uma conversa, mata o convívio, cria insegurança, semeia desesperança. Em quem posso confiar? As confidências tornam-se impossíveis.

O exame jurídico desse tipo de conduta está perfeitamente estabelecido por nossa melhor jurisprudência; mas não é o direito que deve resolver a questão. É a necessidade de convívio, de crença em outra pessoa.

Se alguém procurasse outrem, o visitado deveria ter, pelo menos, a cortesia de advertir o interlocutor de que não compartilhava de suas opiniões e que interrompia a conversa para não ficar desconfortável. Incentivá-la, pretender dar ao outro a falsa impressão de que tudo ficaria em sigilo, é agir de modo atentatório à ética, pois esta é regida pela finalidade de se estabelecer uma afinidade. Ingressando o outro em uma linha censurável, ponha-se fim à conversa. Que, ao se separarem, após o abortamento da tentativa de um acerto inaceitável, cada qual leve em sua inteligência e em seus sentimentos a censura pelo inaceitável e o repúdio pelo ofensivo.

Leve-se em conta, ainda, o que dispõe o art. $5^{\circ}$, LVI, da Constituição, que determina a inadmissibilidade, no processo, das provas obtidas por meios ilícitos; regra destinada a salvaguardar os direitos individuais (BRASIL, 2008). Aliás, há de se considerar que somente se permite a admissão, no processo de provas ilícitas, provenientes da "árvore envenenada", se beneficiarem o acusado. Nesse caso, as provas ilícitas são válidas por se destinarem a resguardar direitos individuais que não apresentem outra forma de provar inocência. Daí há de se concluir, também, que as gravações clandestinas são inadmissíveis, salvo, como proclamam nossas cortes de Justiça, para a defesa de alguém.

\section{CONSIDERAÇÕES FINAIS}

É assustadora a repetição constante de condutas carentes de ética ao 
deixarem de respeitar o conceito de com atribuições de investigar atos que as ações humanas devem guardar ilícitos, assim mesmo, autorizadas por conformidade com os justos fins da decisão judicial respaldada pelo dever vida social e do dever de resguardo à de imparcialidade dos juízes, podem privacidade inerente às prerrogativas quebrar, excepcionalmente, um sigilo dos cidadãos. Somente as autoridades constitucionalmente assegurado.

\section{REFERÊNCIAS}

BRASIL. Constituição da República Federativa do Brasil: promulgada em 5 de outubro de 1988. 41. ed. São Paulo: Saraiva, 2008. 368 p. (Coleção Saraiva de Legislação). 